\title{
ANALISIS FAKTOR-FAKTOR YANG MEMPENGARUHI KEUNTUNGAN USAHA KERIPIK NENAS DI KABUPATEN KAMPAR
}

\author{
(Analysis Of Factors That Affect The Profits Pineapple Chips Business In Kampar Regency) \\ RISKA DIAN OKTARI ${ }^{* *}$, LESTARI RAHAYU WALUYATI², ANY SURYANTINI² \\ ${ }^{1}$ Program Studi Agroteknologi, Fakultas Pertanian dan Peternakan, \\ Universitas Islam Negeri Sultan Syarif Kasim Riau. \\ J.H.R Soebrantas No.155 KM.15 Simpang Baru Panam Pekanbaru Riau 28293 \\ 2 Program Studi Ekonomi Pertanian, Fakultas Pertanian, Universitas Gadjah Mada \\ Jl. Flora, Bulaksumur, Daerah Istimewa Yogyakarta \\ *Email : riskadianoktari@gmail.com
}

\begin{abstract}
The purposes of the research to know the factors that affect the profits in the pineapple chips business. The research was conducted in Tambang Sub-district Kampar Regency Riau Province where the location selection for the research was conducted purposively i.e. selecting the location intentionally, while the method of collecting data was using census method. Research method was using multiple linear regression analysis with OLS (Ordinary Least Square) to determine the factors that affect the profit. The results showed that the factors that affected the profit of pineapple chips business were baking soda prices, shrinkage of vacuum frying machine, the frequency of production and yield, while raw material prices, the price of cooking oil and labor costs did not give a significant influence on profits.
\end{abstract}

Keywords: pineapple chips, profit, multiple linier regression

\section{PENDAHULUAN}

Indonesia merupakan wilayah yang sesuai untuk pengembangan budidaya nenas sehingga memiliki peluang besar dalam memenuhi ketersediaan nenas baik dalam negeri maupun pasar global dimana sentra produksi nenas tersebar diberbagai wilayah Indonesia seperti Lampung, Jawa Barat, Sumatera Utara, Riau dan Jawa Tengah (Pusat Data dan Sistem Informasi Pertanian, 2013).

Produksi nenas di Provinsi Riau pada tahun 2014 mencapai 107.438 ton dengan rata-rata produksi selama 5 tahun terakhir sebesar 85.053 ton (BPS Provinsi Riau, 2015). Sentra produksi nenas tersebar di Kabupaten Indragiri Hilir, Siak, Kampar dan Dumai. Kabupaten Kampar menjadi salah satu sentra produksi nenas di Riau hal ini didukung oleh kondisi daerah yang merupakan lahan gambut sehingga cocok untuk pengembangan komoditas nenas. Pada tahun 2014 jumlah rumpun nenas di Kabupaten Kampar khususnya Kecamatan Tambang mencapai 8.580.000 rumpun dengan produksi $12.870 .000 \mathrm{~kg}$ (BPS Kabupaten Kampar, 2015).

Menurut Hossain (2011) nenas (Ananas comosus $L$ ) adalah buah tropis yang memiliki kandungan gizi tinggi, kaya akan vitamin A, B, C dan mineral (kalsium, fosfor, dan zat besi), serta mengandung senyawa antioksidan flavonoid dan polifenol. Menurut Cahyono (2011) nenas banyak digemari oleh masyarakat baik dalam bentuk buah segar maupun olahan, sehingga memiliki peluang pemasaran yang baik di dalam maupun luar daerah. Pada saat terjadi panen raya, jumlah produksi buah nanas sangat melimpah namun tidak sebanding dengan tingkat konsumsinya sehingga mengakibatkan harga jual nenas menjadi sangat murah dan merugikan petani nenas (Yusmarini dan Setiaries, 2015).

Nenas segar jika disimpan pada suhu ruang akan terfermentasi dan segera membusuk sehingga mengakibatkan distribusi nenas segar menjadi terbatas dan lebih banyak beredar produk nenas olahan di pasaran (Harnanik, 2013). Pengolahan produk dengan bahan baku nenas dapat dilakukan dalam skala industri rumah tangga maupun industri dengan skala yang lebih besar seperti perusahaan. Menurut Rahman (2015) proses pengolahan yang cukup sederhana memberikan peluang diadopsi oleh masyarakat pedesaan, terutama wanita tani sebagai industri rumah tangga (home industry). Kabupaten Kampar merupakan salah satu sentra produksi nenas, masyarakat 
yang tinggal di daerah tersebut memiliki kesempatan untuk dapat mengembangkan produk olahan nenas sehingga dapat memberikan lapangan pekerjaan dan mampu menunjang perekonomian mereka. Beberapa produk olahan nenas yang berkembang adalah keripik nenas, wajik nenas, dodol nenas, puding nenas, selai nenas dan lain sebagainya.

Masyarakat Kabupaten Kampar cenderung mengolah buah nenas menjadi keripik nenas dikarenakan proses pengolahan keripik nenas cukup mudah dilakukan serta daya tahan keripik yang cukup lama yaitu 3-5 bulan meski dalam proses pengolahannya tidak menggunakan tambahan bahan pengawet. Melihat potensi tersebut maka penelitian ini memiliki tujuan untuk mengetahui faktor-faktor yang mempengaruhi keuntungan usaha keripik nenas.

\section{METODE PENELITIAN}

\section{Jenis dan Sumber Data}

Data yang dikumpulkan dalam penelitian terdiri dari data primer dan data sekunder. Data primer diperoleh dari wawancara langsung dengan pengrajin keripik nenas menggunakan daftar pertanyaan (kuesioner) yang terdiri dari keadaan produksi, biaya-biaya, serta harga jual keripik nenas. Sedangkan data sekunder diperoleh dari instansi atau lembaga yang terkait dengan penelitian seperti Dinas Pertanian Kabupaten Kampar, Dinas Perindustrian Perdagangan dan Pasar, serta Badan Pusat Statistik Provinsi Riau, Kabupaten Kampar dan Kecamatan Tambang. Data sekunder dalam penelitian ini antara lain meliputi: keadaan umum wilayah, keadaan pertanian dan perindustrian serta potensi produksi nenas di Kabupaten Kampar Provinsi Riau.

\section{Penentuan Lokasi dan Sampel}

Pemilihan lokasi penelitian dilakukan secara purposive. Penelitian dilaksanakan di Kecamatan Tambang Kabupaten Kampar Provinsi Riau dimana penentuan lokasi didasarkan atas pertimbangan bahwa Kecamatan Tambang merupakan daerah penghasil nenas terbesar di Kabupaten Kampar dan merupakan lokasi sentra pembuatan keripik nenas. Metode pengambilan data dilakukan dengan metode sensus dimana jumlah populasi yang diambil adalah 21 pengrajin keripik nenas di Kecamatan Tambang Kabupaten Kampar.

\section{Metode Pengumpulan Data}

Metode yang digunakan dalam pengumpulan data di lapangan adalah:

1. Wawancara

Metode wawancara digunakan untuk mengumpulkan data primer dengan memberikan daftar pertanyaan (kuesioner) langsung kepada responden.

2. Observasi

Observasi dilakukan untuk mendapatkan gambaran yang jelas mengenai daerah yang akan diteliti.

3. Pencatatan

Teknik pencatatan digunakan untuk mengumpulkan data sekunder yang diperoleh dari dinas, instansi atau lembaga serta literatur yang berhubungan dengan penelitian ini.

\section{Metode Analisis Data}

Analisis faktor-faktor yang mempengaruhi keuntungan usaha keripik nenas menggunakan pendekatan Unit Output Price Cobb-Douglas Profit Function (UOPCDPF) yaitu cara yang dipakai untuk memaksimumkan keuntungan. Dalam analisis, fungsi tersebut ditransformasi dahulu kedalam Logaritma natural (Ln).

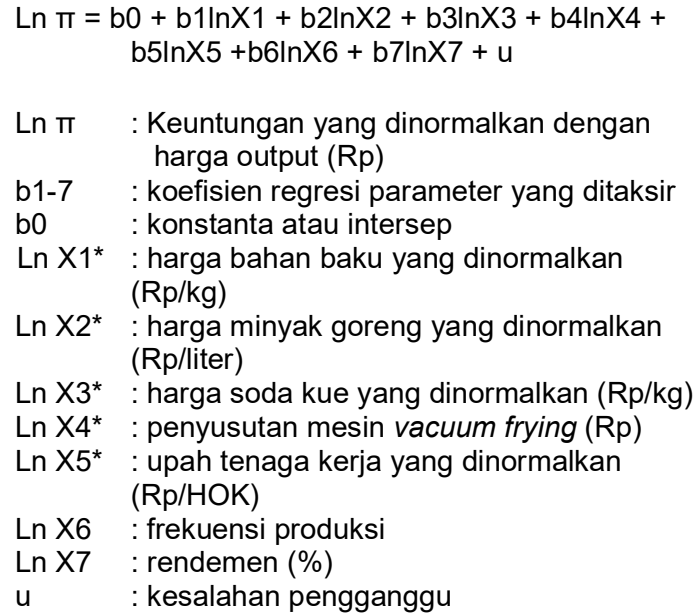

Uji asumsi klasik dilakukan untuk mendeteksi adanya penyimpangan dari asumsi-asumsi klasik. Dalam penelitian ini uji yang digunakan adalah uji normalitas, uji multikolinieritas, dan uji heteroskedastisitas.

\section{HASIL DAN PEMBAHASAN}

\section{Deskripsi Lokasi Penelitian}

Kabupaten Kampar dengan luas lebih kurang 11.289,28 Ha merupakan daerah yang terletak antara 01000'40" Lintang Utara sampai 00027'00" Lintang Selatan dan 100028'30" - 101014'30" Bujur Timur. Batas- 
batas daerah Kabupaten Kampar adalah sebagai berikut:

- Sebelah Utara berbatasan dengan Kota Pekanbaru dan Kabupaten Siak.

- Sebelah Selatan berbatasan dengan Kabupaten Kuantan Singingi.

- Sebelah Barat berbatasan dengan Kabupaten Rokan Hulu dan Propinsi Sumatera Barat.

- Sebelah Timur berbatasan dengan Kabupaten Pelalawan dan Kabupaten Siak.

Di daerah Kabupaten Kampar terdapat dua buah sungai besar dan beberapa sungai kecil yaitu:

- $\quad$ Sungai Kampar yang panjangnya $\pm 413,5$ $\mathrm{km}$ dengan kedalaman rata-rata $7,7 \mathrm{~m}$ dengan lebar rata-rata 143 meter. Seluruh bagian sungai ini termasuk dalam Kabupaten Kampar yang meliputi Kecamatan XIII Koto Kampar, Bangkinang, Kuok, Kampar, Siak Hulu dan Kampar Kiri.

- Sungai Siak bagian hulu yakni penjangnya $\pm 90 \mathrm{~km}$ dengan kedalaman rata-rata 8-12 $\mathrm{m}$ yang melintasi Kecamatan Tapung (BPS Kabupaten Kampar, 2015).

Kecamatan Tambang merupakan salah satu Kecamatan di Kabupaten Kampar dengan luas wilayah $\pm 489,91 \mathrm{Km}^{2}$ atau 53.298,00 Ha. Kecamatan Tambang terdiri dari 17 Desa dengan pusat pemerintahan berada di Desa Sungai Pinang. Tidak ada wilayahnya yang berbatasan dengan laut namun ada sebagian wilayahnya yang dibatasi oleh sungai sebagai batas alam dengan Kecamatan lain.
Sebanyak 12 dari 17 Desa di Kecamatan Tambang dilintasi oleh sungai Kampar yang merupakan salah satu sungai terbesar di Kabupaten Kampar. Kepadatan penduduk sebanyak 62.218 jiwa terdiri dari 30.955 jiwa laki-laki dan 31.263 jiwa perempuan dengan kepadatan penduduk rata-rata $107 \mathrm{jiwa} / \mathrm{Km}^{2}$.

Dilihat dari bentangan wilayah, Kecamatan Tambang berbatasan dengan:

- Sebelah Utara berbatasan dengan Kecamatan Tapung

- Sebelah Timur berbatasan dengan Kecamatan Tampan Kota Pekanbaru

- Sebelah Selatan berbatasan dengan Kecamatan Siak Hulu, Perhentian Raja dan Kampar Kiri Hilir

- Sebelah Barat berbatasan dengan Kecamatan Kampar (BPS Kabupaten Kampar, 2015).

\section{Karakteristik Pengrajin}

Karakteristik pengrajin keripik nenas berkaitan dengan kinerja pengrajin dalam menjalankan usahanya. Usaha keripik nenas di Kecamatan Tambang dilakukan oleh pengrajin dengan berbagai karakteristik yang meliputi umur, tingkat pendidikan, pengalaman usaha serta jumlah anggota keluarga.

1. Umur Pengrajin Keripik Nenas

Umur pengrajin berhubungan dengan kemampuan fisik bekerja dan cara berfikir serta mempengaruhi keterampilan pengrajin dalam mengelola usaha keripik nenas. Pengelompokan umur pengrajin yaitu pada umur (<26), umur (26-60) dan umur $(>60)$.

Tabel 1. Deskripsi Pengrajin Keripik Nenas Menurut Umur Di Kecamatan Tambang Kabupaten Kampar

\begin{tabular}{cccc}
\hline No & Umur (Tahun) & Jumlah (Orang) & Persentase (\%) \\
\hline 1. & $<26$ & 3 & 14,28 \\
2. & $26-60$ & 14 & 66,67 \\
3. & $>60$ & 4 & 19,05 \\
\hline Jumlah & & 21 & 100,00 \\
\hline Sumber: Data Primer, 2016 & &
\end{tabular}

Pada Tabel 1 dapat dilihat bahwa sebanyak 3 pengrajin atau $14,28 \%$ berada pada kelompok umur kurang dari 26 tahun. Pengrajin dengan umur berkisar antara 26 sampai 60 tahun sebanyak 14 pengrajin $(66,67 \%)$ sedangkan sisanya sebanyak 4 pengrajin atau $19,05 \%$ berada pada umur lebih dari 64 tahun. Hal ini menunjukkan bahwa pengrajin keripik nenas di Kecamatan Tambang Kabupaten Kampar masih memiliki kemampuan fisik dan cara berfikir yang baik dalam menjalankan usahanya.

\section{Tingkat Pendidikan}

Tingkat pendidikan baik formal maupun non formal berpengaruh terhadap peningkatan produksi (Siradjuddin, 2012). Tingkat pendidikan pengrajin keripik nenas juga berpengaruh terhadap kemampuan dalam menyerap maupun menerima informasi serta teknologi demi pengembangan usaha keripik nenas kearah yang lebih baik. Semakin tinggi pendidikan seseorang maka semakin tinggi kemampuan dalam mengadopsi teknologi yang dapat menunjang usahanya. Tingkat pendidikan pengrajin meliputi pendidikan SD, SMP, SMA, serta D3/S1. 
Tabel 2. Deskripsi Pengrajin Keripik Nenas Menurut Tingkat Pendidikan di Kecamatan Tambang Kabupaten Kampar

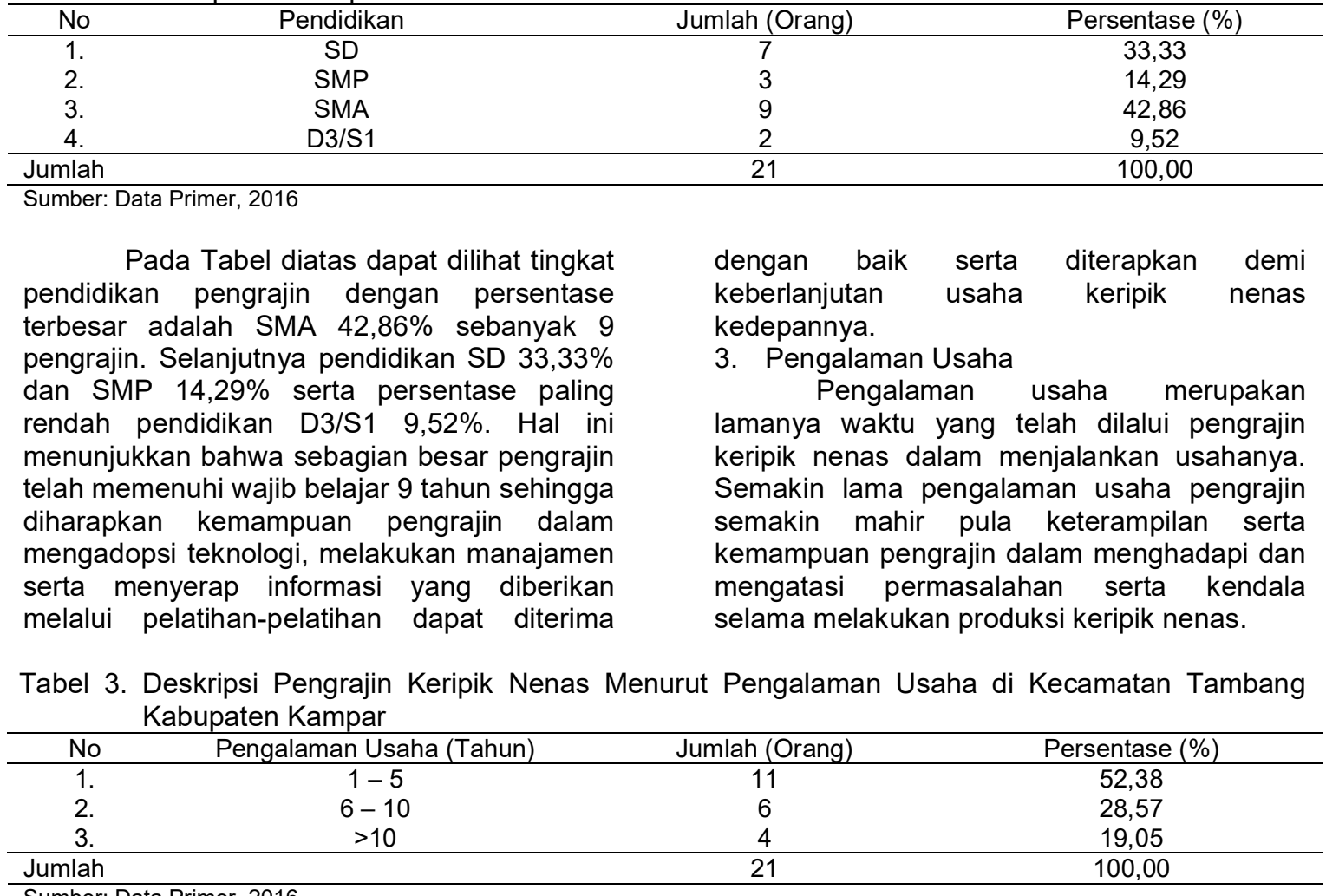

Sumber: Data Primer, 2016

Tabel 3 menunjukkan pengalaman usaha pengrajin antara 1-5 tahun dengan persentase $52,38 \%$ serta lama usaha 6-10 tahun sebesar $28,57 \%$. Sedangkan pengrajin dengan pengalaman usaha lebih dari 10 tahun sebesar 19,05\%. Hal ini menunjukkan sebagian besar pengrajin keripik nenas sudah cukup lama dan berpengalaman dalam menjalankan usahanya.

\section{Jumlah Anggota Keluarga}

Jumlah anggota keluarga memberikan pengaruh terhadap keberlanjutan usaha keripik nenas. Jika sebagian anggota keluarga berusia produktif maka memberikan sumbangan tenaga kerja dalam keluarga yang dapat membantu dalam pengembangan usaha keripik nenas ini.

Tabel 4. Deskripsi Pengrajin Keripik Nenas Menurut Jumlah Anggota Keluarga di Kecamatan Tambang Kabupaten Kampar

\begin{tabular}{cccc}
\hline No & Anggota Keluarga (Orang) & Jumlah (Orang) & Persentase $(\%)$ \\
\hline 1. & $<3$ & 11 & 52,38 \\
2. & $3-5$ & 9 & 42,86 \\
3. & $>5$ & 1 & 4,76 \\
\hline Jumlah & & 21 & 100,00 \\
\hline
\end{tabular}

Sumber: Data Primer, 2016

Tabel 4 menunjukkan persentase jumlah anggota keluarga kurang dari 3 orang sebesar $52,38 \%$ dan jumlah anggota keluarga 3-5 orang sebesar $42,86 \%$ serta lebih besar dari 5 orang $4,76 \%$. Jumlah anggota keluarga memberikan kontribusi terhadap penyediaan tenaga kerja dalam keluarga. Sebagian besar anggota keluarga pengrajin keripik nenas masih tergolong dalam usia sekolah sehingga belum memberikan kontribusi yang cukup besar dalam membantu usaha keluarga tersebut. Usaha keripik nenas ini lebih banyak dijalankan oleh suami dan istri sebagai tenaga kerja dalam keluarga. Selain itu jumlah anggota keluarga juga mempengaruhi banyaknya kebutuhan hidup pengrajin. Semakin banyak jumlah anggota keluarga semakin besar pula kebutuhan hidupnya sehingga perlu ditunjang dengan penghasilan yang cukup agar kesejahteraan pengrajin menjadi lebih baik. 


\section{Profil Usaha Keripik Nenas}

Usaha keripik nenas di Kabupaten Kampar merupakan usaha yang tergolong industri rumah tangga dimana proses produksi dilakukan dirumah maupun tempat usaha masing-masing pengrajin. Usaha keripik nenas merupakan kegiatan pengolahan buah nenas menjadi keripik nenas dengan tambahan bahan penunjang yang terdiri dari minyak goreng, garam, dan soda kue dimana proses pemasakannya menggunakan mesin vacuum frying. Buah nenas memiliki kandungan air yang cukup tinggi sehingga jika ingin mengolahnya menjadi keripik harus menggunakan mesin penggorengan hampa. Pengolahan keripik nenas tidak bisa dilakukan dengan proses penggorengan biasa karena akan menyebabkan buah nenas menjadi rusak yang disebabkan oleh pemasakan pada suhu yang tinggi.

Tahapan proses pengolahan buah nenas menjadi keripik nenas terdiri dari pengupasan kulit nenas, perajangan nenas, perendaman nenas dengan garam dan soda, pemasakan dengan mesin vacuum frying, dan penirisan keripik nenas. Bahan baku yang merupakan bahan utama dalam pengolahan keripik nenas adalah buah nenas segar, sedangkan bahan penunjang terdiri dari minyak goreng, garam dan soda kue. Pengolahan buah nenas menjadi keripik nenas menggunakan mesin penggorengan hampa atau vacuum frying karena buah dengan kandungan air yang tinggi tidak dapat digoreng dengan sistem penggorengan biasa. Buah nenas digoreng menggunakan mesin vacuum frying pada suhu rendah yaitu $84^{\circ} \mathrm{C}$ sehingga nenas dapat diolah menjadi keripik yang renyah.

\section{Analisis Faktor-Faktor yang Mempengaruhi Keuntungan Usaha Keripik Nenas}

Untuk mengetahui faktor-faktor yang mempengaruhi keuntungan usaha keripik nenas menggunakan analisis regresi linier berganda dengan metode kuadrat terkecil atau Ordinary Least Square (OLS) dalam bentuk logaritma natural (Ln). Analisis menggunakan fungsi keuntungan Unit Output Price (UOP) dimana dalam perhitungannya nilai keuntungan dinormalkan atau dibagi dengan harga output keripik nenas, demikian juga dengan harga input lainnya dinormalkan dengan harga output. Pengolahan data menggunakan program EViews 8 dengan nilai keuntungan yang diperoleh pengrajin keripik nenas sebagai variabel dependen dan variabel harga bahan baku, harga minyak goreng, harga soda kue, penyusutan mesin vacuum frying, upah tenaga kerja, frekuensi produksi serta rendemen sebagai variabel independen.

\section{Uji Asumsi Klasik \\ Uji Normalitas}

Uji normalitas yang dilakukan menggunakan uji Jarque-Bera dengan taraf signifikasi (a) sebesar 5\%. Data dinyatakan berdistribusi normal apabila nilai Jarque-Bera lebih kecil dari nilai Chi-Square atau nilai probabilitas lebih besar dari alfa ( $\alpha)$.

Tabel 5. Hasil Uji Normalitas

\begin{tabular}{lr}
\hline Jarque-Bera & 0,25473 \\
Probability & 0,88041 \\
\hline
\end{tabular}

Sumber: Data Diolah, 2016

Pada tabel diatas dapat dilihat nilai Jarque-Bera sebesar 0,25473 berdasarkan jumlah variabel independen maka degree of freedom $(\mathrm{df})=7$ dan $\alpha=5 \%$ sehingga didapat nilai Chi-Square Distribution Table sebesar 14,07 yang berarti nilai J-B lebih kecil dari nilai Chi Square Distribution Table sehingga dapat disimpulkan bahwa data berdistribusi normal. Pengujian normalitas juga dapat dilihat dari nilai probabilitas 0,88 lebih besar dari alfa $(\alpha)$ 0,05 dengan demikian data yang digunakan dalam penelitian sudah berdistribusi normal.

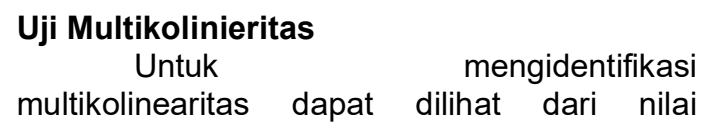

Variance Inflation Factor (VIF) pada masingmasing variabel independen. Apabila suatu variabel independen mempunyai nilai VIF > 10 berarti telah terjadi masalah multikolinieritas dimana terdapat korelasi yang kuat diantara variabel-variabel independen dalam model.

Berdasarkan uji multikolinearitas pada tabel diatas dapat dilihat bahwa nilai Variance Inflation Factor (VIF) pada masing-masing variabel independen lebih kecil dari 10 artinya variabel-variabel independen yang terdiri dari harga bahan baku, harga minyak goreng, harga soda kue, penyusutan mesin vacuum frying, upah tenaga kerja, frekuensi produksi dan rendemen terbebas dari gejala multikolinearitas. 
Tabel 6. Uji Multikolinieritas

\begin{tabular}{cc}
\hline Variabel & VIF \\
\hline Harga Bahan Baku & 2,271899 \\
Harga M. Goreng & 2,224718 \\
Harga Soda Kue & 2,343848 \\
Penyusutan Mesin & 2,465324 \\
Upah Tenaga Kerja & 3,933498 \\
Frekuensi Produksi & 3,388316 \\
Rendemen & 1,065894 \\
\hline
\end{tabular}

Sumber: Data Diolah, 2016

\section{Uji Heteroskedastisitas}

Untuk mendeteksi adanya heteroskedastisitas pada model maka dilakukan pengujian menggunakan uji White Heteroscedasticity. Apabila nilai probabilitas chi-square pada obs ${ }^{\star} R$-Squared lebih besar dari alfa (a) maka tidak terdapat masalah heteroskedastisitas.

Pada tabel diatas dapat dilihat nilai Obs ${ }^{*} \mathrm{R}$-Squared sebesar 8,0771 berdasarkan jumlah variabel independen maka diperoleh degree of freedom (df) $=7$ dengan $\alpha=5 \%$ dan didapat nilai Chi-Square Distribution Table sebesar 14,07 yang berarti nilai $\mathrm{Obs}^{\star} \mathrm{R}$ Squared lebih kecil dari nilai Chi-Square Distribution Table sehingga dapat disimpulkan bahwa model terbebas dari heteroskedastisitas. Selain itu, pengujian heteroskedastisitas dapat dilihat dari nilai probabilitas Chi-Square pada obs ${ }^{*} \mathrm{R}$-Squared 0,3258 lebih besar dari a (alfa) 0,05 sehingga tidak terdapat masalah heteroskedastisitas.

Tabel 7. Uji Heteroskedastisitas

\begin{tabular}{llll}
\hline F-statistic & 1,160769 & Prob. F(7,13) & 0,3867 \\
Obs*R-squared & 8,077156 & Prob. Chi-Square $(7)$ & 0,3258 \\
Scaled explained SS & 3,203838 & Prob. Chi-Square(7) & 0,8655 \\
\hline
\end{tabular}

Sumber: Data Diolah, 2016

\section{Uji Statistik}

Uji statistik dilakukan dimana variabel dependen adalah keuntungan dan variabel independen adalah harga bahan baku, harga minyak goreng, harga soda, penyusutan mesin vacuum frying, upah tenaga kerja, frekuensi produksi dan rendemen. Hasil analisis faktorfaktor yang mempengaruhi keuntungan keripik nenas dapat dilihat pada Tabel 8.

Tabel 8. Hasil Analisis Regresi Linier Berganda Faktor-Faktor yang Mempengaruhi Keuntungan Usaha Keripik Nenas

\begin{tabular}{|c|c|c|c|}
\hline Variable & Coefficient & t-statistic & Prob. \\
\hline Konstanta & 6,242522 ns & 1,455098 & 0,1694 \\
\hline Harga Bahan Baku & $0,670955 \mathrm{~ns}$ & 0,568500 & 0,5794 \\
\hline Harga Minyak Goreng & $-0,430792$ ns & $-0,474972$ & 0,6427 \\
\hline Harga Soda Kue & 0,370909 * & 1,927233 & 0,0761 \\
\hline Penyusutan Mesin & $-0,724863^{* *}$ & $-2,697763$ & 0,0183 \\
\hline Upah Tenaga Kerja & $0,267278 \mathrm{~ns}$ & 1,202995 & 0,2504 \\
\hline Frekuensi Produksi & $0,881244 * * *$ & 3,950498 & 0,0017 \\
\hline Rendemen & 1,907333 * & 1,956092 & 0,0723 \\
\hline Adjusted R-squared & & \multicolumn{2}{|c|}{0,794926} \\
\hline F-statistic & & \multicolumn{2}{|c|}{12,07510} \\
\hline Prob(F-statistic) & & \multicolumn{2}{|c|}{0,000088} \\
\hline $\begin{array}{r}\text { Keterangan: }{ }^{* *}=\text { signifika } \\
{ }^{* *}=\text { signifika } \\
{ }^{*}=\text { signifikan } \\
\text { ns }=\text { tidak si } \\
\text { Sumber: Dat }\end{array}$ & $\begin{array}{l}\operatorname{yaan} 99 \%(\alpha=0,0 \\
\operatorname{aan} 95 \%(\alpha=0,0 \\
\operatorname{aan} 90 \%(\alpha=0,1)\end{array}$ & & \\
\hline
\end{tabular}




\section{Uji Koefisien Determinasi (Adjusted $\boldsymbol{R}^{2}$ )}

Uji Koefisien determinasi (Adjusted $R^{2}$ ) menunjukkan besarnya proporsi atau persentase kemampuan variabel independen untuk menjelaskan variabel dependen yaitu keuntungan. Dari hasil analisis nilai Adjusted $R^{2}$ sebesar 0,7949 artinya variabel keuntungan dapat dijelaskan oleh variabel harga bahan baku, harga minyak goreng, harga soda, penyusutan mesin vacuum frying, upah tenaga kerja, frekuensi produksi dan rendemen sebesar $79,49 \%$ dan sisanya dijelaskan variabel lain yang tidak dimasukkan kedalam model. Dengan demikian, model memiliki kelayakan yang baik untuk mengidentifikasi faktor-faktor yang mempengaruhi keuntungan keripik nenas.

\section{Uji F}

Uji $F$ digunakan untuk mengetahui pengaruh semua variabel independen secara bersama-sama terhadap variabel dependen. Hasil analisis menunjukkan nilai F-statistic atau F hitung sebesar 12,0751 lebih besar dari $F$ tabel 2,832 dan probabilitas F-statistic 0,000088 lebih kecil dari $\alpha=5 \%$. Hal ini menunjukkan bahwa variabel independen yaitu harga bahan baku, harga minyak goreng, harga soda kue, penyusutan mesin vacuum frying, upah tenaga kerja, frekuensi produksi serta rendemen secara bersama-sama berpengaruh signifikan terhadap variabel dependen yaitu keuntungan pada tingkat kepercayaan 95\%.

\section{Uji t}

Uji $t$ dilakukan untuk mengetahui pengaruh masing-masing variabel independen yaitu harga bahan baku, harga minyak goreng, harga soda kue, penyusutan mesin vacuum frying, upah tenaga kerja, frekuensi produksi serta rendemen terhadap variabel dependen yaitu keuntungan. Uji $t$ dilakukan dengan membandingkan nilai probabilitas (signifikansi) masing-masing variabel independen pada a masing-masing sebesar $1 \%, 5 \%$, dan $10 \%$.

1. Harga Bahan Baku

Hasil analisis menunjukkan nilai koefisien regresi sebesar 0,6710 dengan nilai $t$ statistic atau $\mathrm{t}$ hitung 0,5685 lebih kecil dari $\mathrm{t}$ tabel dan signifikansi 0,5794 lebih besar dari $\alpha$ sehingga harga bahan baku nenas tidak berpengaruh signifikan terhadap keuntungan.

2. Harga Minyak Goreng

Nilai koefisien sebesar $-0,4308$ dengan nilai t hitung $-0,4749$ lebih kecil dari t tabel dan signifikansi 0,6427 lebih besar dari a sehingga variabel harga minyak goreng tidak berpengaruh secara signifikan terhadap keuntungan.

3. Harga Soda Kue

Nilai koefisien regresi pada variabel harga soda kue sebesar 0,3709 dengan nilai $t$ hitung 1,9272 lebih besar dari t tabel yaitu 1,771 dengan signifikansi 0,0761 lebih kecil dari $\alpha$ $=10 \%$ artinya variabel harga soda kue berpengaruh signifikan secara positif terhadap keuntungan pada tingkat kepercayaan 90\%. Jika harga soda naik sebesar $1 \%$ maka akan meningkatkan keuntungan sebesar 0,3709\% (ceteris paribus).

Terdapat dua jenis soda kue yang digunakan pengrajin keripik nenas yaitu soda dengan kualitas yang lebih bagus harganya lebih mahal daripada soda kue yang berkualitas rendah. Jenis soda kue yang digunakan mempengaruhi kualitas keripik nenas yang dihasilkan, hal ini dikarenakan kualitas soda kue yang lebih baik akan menghasilkan keripik nenas yang lebih renyah dengan harga jual yang lebih tinggi sehingga keuntungan yang diperoleh pengrajin juga lebih besar.

4. Penyusutan Peralatan Mesin Vacuum Frying

Nilai koefisien regresi pada variabel penyusutan mesin Vacuum Frying sebesar 0,7249 dengan nilai $t$ hitung sebesar 2,6977 lebih besar dari $t$ tabel 2,160 dan signifikansi 0,0183 lebih kecil dari $\alpha=5 \%$ artinya variabel ini berpengaruh signifikan secara negatif terhadap keuntungan pada tingkat kepercayaan 95\%. Jika penyusutan mesin naik sebesar 1\% akan menyebabkan keuntungan berkurang sebesar 0,7249\% (ceteris paribus).

Buah nenas memiliki kandungan air yang tinggi sehingga jika ingin diolah menjadi keripik nenas tidak dapat menggunakan metode penggorengan biasa. Pengolahan keripik buah dapat dilakukan dengan menggunakan mesin vacuum frying atau mesin penggorengan hampa. Menurut Fatmawati (2018) penyusutan mesin termasuk dalam perhitungan biaya tetap yaitu biaya yang tidak mengalami perubahan dalam kurun waktu tertentu meskipun terjadi perubahan produksi. Biaya penyusutan terutama penyusutan mesin merupakan biaya tetap yang paling besar dan berpengaruh terhadap keuntungan (Karsiningsih, 2016). Penyusutan mesin vacuum frying yang semakin besar menyebabkan penambahan biaya tetap, sehingga keuntungan yang diperoleh juga akan semakin rendah. 


\section{Upah Tenaga Kerja}

Nilai koefisien regresi pada variabel upah tenaga kerja sebesar 0,2673 dengan nilai $t$ hitung sebesar 1,2029 lebih kecil dari t tabel dan signifikansi sebesar 0,2504 lebih besar dari a sehingga variabel upah tenaga kerja tidak berpengaruh secara signifikan terhadap keuntungan.

\section{Frekuensi Produksi}

Nilai koefisien regresi pada variabel frekuensi produksi sebesar 0,8812 dengan nilai t hitung sebesar 3,9504 lebih besar dari nilai $t$ tabel 3,012 dan nilai signifikansi 0,0017 lebih kecil dari $\alpha=1 \%$ artinya variabel frekuensi produksi berpengaruh signifikan positif terhadap keuntungan pada tingkat kepercayaan $99 \%$. Jika frekuensi produksi naik sebesar $1 \%$ akan meningkatkan keuntungan keripik nenas sebesar $0,8812 \%$ (ceteris paribus).

Frekuensi produksi adalah seberapa sering pengrajin melakukan proses produksi keripik nenas, jika pengrajin melakukan proses produksi lebih sering, maka produksi keripik nenas yang dihasilkan lebih besar dan keuntungan yang diperoleh juga akan semakin tinggi.

7. Rendemen

Nilai koefisien regresi pada variabel rendemen sebesar 1,9073 dengan nilai t hitung sebesar 1,9561 lebih besar dari $t$ tabel 1,771 dan signifikansi 0,0723 lebih kecil dari $\alpha=10 \%$ artinya variabel ini berpengaruh signifikan secara positif terhadap keuntungan pada tingkat kepercayaan $90 \%$. Jika rendemen naik sebesar $1 \%$ akan menyebabkan keuntungan meningkat sebesar $1,9073 \%$ (ceteris paribus).

Rendemen merupakan persentase jumlah keripik nenas yang dihasilkan dibagi dengan jumlah bahan baku nenas. Jika pengrajin dalam melakukan proses produksi keripik nenas dapat memaksimalkan rendemen yang dihasilkan, maka produksi keripik akan lebih besar dan keuntungan yang diperoleh juga akan semakin tinggi.

\section{KESIMPULAN DAN SARAN}

\section{Kesimpulan}

Faktor-faktor yang mempengaruhi keuntungan pada usaha keripik nenas adalah harga soda kue, penyusutan mesin vacuum frying, frekuensi produksi dan rendemen. Harga soda kue, frekuensi produksi dan rendemen memberikan pengaruh positif signifikan terhadap keuntungan sedangkan penyusutan mesin vacuum frying berpengaruh negatif signifikan terhadap keuntungan. Harga bahan baku, harga minyak goreng dan upah tenaga kerja tidak memberikan pengaruh secara signifikan terhadap keuntungan keripik nenas.

\section{Saran}

1. Bagi pemerintah, adanya pembinaan dan pelatihan yang berkelanjutan guna meningkatkan kemampuan pengrajin dalam melakukan proses pengolahan keripik nenas sehingga kualitas produk yang dihasilkan lebih baik.

2. Bagi pengrajin sebaiknya menggunakan soda kue berkualitas baik agar keripik nenas yang dihasilkan memiliki kualitas yang baik pula dengan harga jual yang lebih tinggi sehingga keuntungan yang diperoleh pengrajin dapat lebih besar.

\section{DAFTAR PUSTAKA}

Badan Pusat Statistik (BPS). 2015. Kampar dalam Angka. BPS Kabupaten Kampar. Bangkinang

2015. Riau dalam Angka. BPS Provinsi Riau. Pekanbaru 2015. Statistik Kecamatan Tambang. BPS Kabupaten Kampar. Bangkinang

Cahyono, B. 2011. Buku Terlengkap Budidaya Nenas secara Komersial. Pustaka Mina. Jakarta.

Fatmawati, I., Fatmawati dan Lestari, Sri. 2018. Kelayakan Finansial Agroindustri Kopi Lengkuas di Desa Matanair, Kecamatan Rubaru, Kabupaten Sumenep. Jurnal Sosial Ekonomi dan Kebijakan Pertanian Agriekonomika. 7 (2). 176-187

Harnanik, S. 2012. Perbaikan Mutu Pengolahan Nenas Dengan Teknologi Olah Minimal Dan Peluang Aplikasinya Di Indonesia. Jurnal Litbang Pertanian. 32 (2): $67-75$

Hossain, M.A and M.M.A. Rahman. 2011. Total phenolics,flavonoids and antioxidant activity of tropical fruit pineapple. Food Research International. 44: 672-676

Karsiningsih, E. 2016. Analisis Kelayakan Finansial dan Strategi Pengembangan Teh Gaharu di Kabupaten Bangka Tengah (Studi Kasus: Teh Gaharu "Aqilla" Gapoktan Alam Jaya Lestari). Journal of Agribusiness and Rural Development Research. 2 (2): 143-151 
Pusat Data dan Sistem Informasi Pertanian. 2013. Informasi Komoditas Hortikultura. No. 04/03/l. Jakarta

Rahman, S. 2015. Analisis Nilai Tambah Agroindustri Chips Jagung. Jurnal Aplikasi Teknologi Pangan. 4 (3): 108111

Siradjuddin, I. 2012. Dampak Pengembangan Kapas Transgenik Terhadap Serapan Tenaga Kerja Dan Pendapatan
Daerah Di Kabupaten Takalar, Bantaeng, Dan Bulukumba. Jurnal Agroteknologi. 3 (1): 21-28

Yusmarini, E dan J. V. Setiaries. 2015. Karakterisasi Mutu Kimiawi, Mikrobiologi Dan Sensori Sari Buah Campuran Nanas Dan Semangka. Jurnal Teknologi dan Industri Pertanian Indonesia. 7 (1): 18-23 